\title{
In situ grazing rates and daily ration of Antarctic krill Euphausia superba feeding on phytoplankton at the Antarctic Polar Front and the Marginal Ice Zone
}

\author{
R. Perissinotto ${ }^{1, *}$, E. A. Pakhomov ${ }^{2}$, C. D. McQuaid ${ }^{2}$, P. W. Froneman ${ }^{2}$ \\ ${ }^{1}$ Department of Zoology, University of Fort Hare, Private Bag X1314, Alice 5700, South Africa \\ ${ }^{2}$ Southern Ocean Group, Department of Zoology \& Entomology, Rhodes University, PO Box 94, Grahamstown 6140, South Africa
}

\begin{abstract}
Measurements of krill gut pigment content, evacuation rates and digestive efficiency were obtained during January 1993 in the Atlantic sector of the Southern Ocean, between the Antarctic Marginal Ice Zone (MIZ) and the Polar Front Zone (PFZ). These were combined with net and acoustically derived abundance and biomass data to estimate the in situ grazing of Euphausia superba on the phytoplankton assemblages. Individual ingestion rates of krill were 1.5 to 3 times higher than rates previously obtained with in vitro incubations. Gut pigment levels and evacuation rates varied in the range of 0.01 to $10 \mu \mathrm{g}$ chlorophyll $a$ equivalents (chl a equiv.) ind ${ }^{-1}$ and 0.10 to $0.31 \mathrm{~h}^{-1}$, respectively. Pigment losses to non-fluorescing products during digestion were very high, in the range of 67 to $90 \%$ of the total pigment ingested, indicating that some of the gut pigment levels previously obtained without correction for digestive losses may have been underestimated by up to an order of magnitude. Krill population impact on the phytoplankton stock exhibited a large variability, in the range of 0.0014 to $2.68 \%$ of total integrated chlorophyll $a$ and 0.023 to $50.8 \%$ of primary production consumed per day. The largest variations in impact levels were associated with the method used to estimate krill abundance and biomass, with net derived estimates being much lower (by as much as 2 orders of magnitude) than those obtained from acoustic data. Daily carbon rations obtained from our measurements of pigment ingestion rates are among the lowest recorded for E. superba during the summer season and, with 1 exception, ranged between 0.15 and $1.68 \%$ of body carbon per day. A daily ration of $\sim 13 \%$ body carbon was recorded only at 1 station in the MIZ which exhibited a dense phytoplankton bloom of $-35 \mu \mathrm{g} \mathrm{chl} \mathrm{l}^{-1}$ On the basis of the energetic requirements of the summer krill population, it is suggested that throughout the PFZ and the MIZ E. superba must consume a much larger proportion of heterotrophic carbon than previously supposed. Gut content analysis suggests that this is achieved by predation on meso- and microzooplankton.
\end{abstract}

KEY WORDS: Antarctic krill - Euphausia superba - Grazing rates - Daily ration - Southern Ocean

\section{INTRODUCTION}

Biomass of krill Euphausia superba in Antarctic waters generally accounts for $\sim 50 \%$ of the total zooplankton stock (Holdgate 1967, Holm-Hansen \& Huntley 1984). The grazing impact of this species on the phytoplankton of the Southern Ocean is expected to be substantial and to represent a major pathway in the vertical transport of particulate organic carbon to the deep ocean via production of large faecal pellets and diumal vertical migration (Tanoue \& Hara 1986.

-E-mail: renzo@zoo.ufh.ac.za
Smetacek et al. 1990, Cadée et al. 1992). Krill food consumption has generally been estimated indirectly, by adding together the energy required for production, respiration, excretion and other energetic costs (Clarke \& Morris 1983, Price et al. 1988, Huntley et al. 1994). Until very recently, the only direct estimates were obtained from in vitro incubations (Antezana et al 1982, Boyd et al. 1984, Schnack 1985). However, due to bottle containment effects, there are indications that rate measurements derived in this way may have been systematically biased and misinterpreted, even when flow-through systems have been used (Morris 1984, Price et al. 1988). 
The gut fluorescence method is at present the most widely used technique for the measurement of in situ feeding rates of zooplankton on phytoplankton. In the case of the Antarctic krill, this method has been recently employed to investigate qualitative aspects of its feeding activity, such as diumal rhythms and swarm grazing behaviour (Morris \& Ricketts 1984, Priddle et al. 1990). In only a few instances (Quetin et al. 1987, Daly 1990, Drits \& Pasternak 1993) have both gut pigment content $(G)$ and evacuation rate $(k)$ been measured and combined to estimate ingestion rates of adults (summer and fall) and furcilia larvae (winter). In all these studies, however, gut evacuation rates were determined by measuring the decline in gut pigments in non-feeding krill, kept in filtered seawater for periods of 6 to $24 \mathrm{~h}$. When not feeding, euphausiids can retain food in their guts for periods of up to $2 \mathrm{~d}$ (Lasker 1966, Willason \& Cox 1987). Thus, accurate evacuation rates can be obtained only when krill are incubated under continuous feeding conditions (Willason \& Cox 1987, Perissinotto 1992, Perissinotto \& Pakhomov 1996, Pakhomov et al. 1997).

Furthermore, it is now clear that the gut fluorescence method requires that the proportion of ingested chlorophyll a that is destroyed or broken down to non-fluorescent end products be measured in conjunction with the other grazing parameters. This is because losses often reach levels $\geq 50 \%$ of the total pigment ingested (Conover et al. 1986, Lopez et al. 1988, Penry \& Frost 1991, Mayzaud \& Razouls 1992, Perissinotto \& Pakhomov 1996). In this study, measurements of gut pigment content, evacuation rate and pigment degradation are combined in an attempt to provide estimates of in situ grazing rates and daily rations in Antarctic krill.

\section{MATERIALS AND METHODS}

All samples and measurements were taken in January 1993 in the Atlantic sector of the Southern Ocean along the Greenwich Meridian, between the SANAE (South African National Antarctic Expedition) station, on the Antarctic continent, and the Antarctic Polar Front (APF). This formed part of the second cruise of the South African Antarctic Marine Ecosystem Study (SAAMES II) aboard the SA 'Agulhas' along the WOCE SR2 line. Conductivity, temperature and depth (CTD) profiles were obtained at regular intervals of $\sim 10^{\prime}$ latitude using a Neil Brown MK III probe. At each station, samples for analysis of nutrients and photosynthetic pigments were collected with 81 Niskin bottles mounted on a 12 bottle rosette system (General Oceanics).

Chlorophyll $a$ and phaeopigment concentrations were measured in 200 to $1000 \mathrm{ml}$ aliquots taken from the Niskin samples at standard depths of $0,20,30,50$, $75,100,125,150,200,250$ and $300 \mathrm{~m}$. Generally, pig- ment fractionation into pico $(<2 \mu \mathrm{m})$, nano (2 to $20 \mu \mathrm{m})$ and micro $(>20 \mu \mathrm{m})$ size classes was carried out only on the surface samples $(0 \mathrm{~m})$. For this purpose, Whatman GF/F, $2.0 \mu \mathrm{m}$ Nuclepore and $20 \mu \mathrm{m}$ Nitex filters were used in a multiple serial filtration manifold. Pigments were extracted for $24 \mathrm{~h}$ in polyethylene tubes with $8 \mathrm{ml}$ of $90 \%$ acetone and concentrations measured with a Turner Designs fluorometer.

Daily primary production rates were measured at 5 out of the 14 grazing stations by $24 \mathrm{~h}$ dawn-to-dawn, in situ-simulated deck incubations (JGOFS 1990). Water was obtained from the $100,50,25,10,5$ and $1 \%$ subsurface light-depths and pre-filtered through a $200 \mu \mathrm{m}$ mesh to remove grazers. For each light level, 3 replicate polycarbonate bottles were inoculated with 25 to $50 \mu \mathrm{Ci}$ of $\mathrm{NaH}^{14} \mathrm{CO}_{3}$ (Amersham) and incubated on deck for $24 \mathrm{~h}$ in running surface seawater to maintain ambient temperature. The specific activity was obtained by removing and filtering aliquots from each productivity bottle. Filters were then placed in liquid scintillation vials with $10 \mathrm{ml}$ fluor and their radioactivity was measured on board using a Beckman scintillation counter.

Quantitative microphytoplankton (>20 $\mu \mathrm{m}$ ) samples were collected from the upper surface layer $(\sim 5 \mathrm{~m})$ using a $20 \mu \mathrm{m}$ mesh filtration unit connected to a shipboard pump (Iwaki Magnet Pump) operated at a flow rate of $\sim 51 \mathrm{~min}^{-1}$ (Berman \& Kimor 1983). A constant volume of 201 was filtered at each station, cells were rinsed off the filter and preserved in $2 \%$ hexaminebuffered formalin solution. The major phytoplankton taxa in aliquots retained by the filter were counted using an inverted microscope, after sedimentation in $10 \mathrm{ml}$ chambers (Hasle 1978). The aim of this was to provide an indication of the species composition of the larger phytoplankton in the area.

Krill biomass was determined from net tows (RMT-8 and $500 \mathrm{\mu m}$ Bongo nets) and acoustically, using a SIMRAD EK500 sounder operated at a frequency of $120 \mathrm{kHz}$ (SIMRAD 1991). The output parameter of the sounder echo-integrator was $S_{\mathrm{A}}\left(\mathrm{m}^{2} / \mathrm{nm}^{2}\right)$, the mean backscattering area per unit of horizontal area. This was converted to mean volume backscattering strength, $S_{V}$, using the relation (SIMRAD 1991):

$$
S_{V}=10 \log _{10}\left\{S_{\mathrm{A}} /\left[4 \pi r_{0}^{2}(1852 \mathrm{~m} / \mathrm{nm})^{2}\left(r_{2}-r_{1}\right)\right]\right\}
$$

Where $r_{0}=$ reference range for backscattering strength $(1 \mathrm{~m})$ and $r_{1}$ and $r_{2}$ are the upper and lower depths of the layer (in $\mathrm{m}$ ), respectively. The coefficient $S_{V}$ is related to the density $(\rho)$ of scatterers (ind. $\mathrm{m}^{-3}$ ) through the equation (Stanton et al. 1987):

$$
S_{V}=10 \log \rho+T S \text {, and thus: } \rho=10 \exp \left(S_{V}-T S\right) 0.1
$$

$T S$ is the average target strength of krill and was derived from the length, $L$ (in $\mathrm{mm}$ ), of the individuals 
collected in the net hauls (Greene et al. 1991, SCCAMLR 1991):

$$
T S=34.85 \log L-127.45
$$

Krill were collected at 14 stations along the SANAEAPF transect. Generally, 1 oblique Bongo tow to a depth of $300 \mathrm{~m}$ was carried out at each station to investigate the spatial variation in krill biomass and grazing activity. In the vicinity of the APF (Stn WR-22), Bongo tows were repeated at $2.5 \mathrm{~h}$ intervals for a $24 \mathrm{~h}$ period. One sample from each net tow was preserved with $4 \%$ buffered formalin for abundance and length/weight analysis, while the second sample was used for measurements of $G$ and $k$. For the analysis of the gut pigment content, fresh krill were picked from a 2 l PVC cod-end and put into $10 \mathrm{ml}$ polypropylene tubes ( 1 individual per tube) where pigments were extracted with pure methanol for 6 to $12 \mathrm{~h}$ (Simard et al. 1985). After centrifugation $(5000 \mathrm{rpm}, \sim 1740 \times g)$, the pigment content of the methanol extract was measured with a Turner 111 fluorometer, before and after acidification.

Total pigment content was obtained using the formulas of Strickland \& Parsons (1968) as modified by Conover et al. (1986). It must be noted, however, that recent work by Head \& Harris (1992) and Welshmayer (1994) has shown that the wide-band pass filters generally used in fluorometry may result in an overestimation of the concentration of chlorophyll degradation products. In this study, chlorophyll a and phaeopigment concentrations were added together and expressed in units of chlorophyll a equivalents (chl a equiv.) (Conover et al. 1986). Three to 10 replicate individuals were used for pigment extraction and measurement from each tow.

During the gut evacuation experiments, freshly collected krill were incubated in filtered seawater to which non-fluorescent charcoal powder was added to keep the animals under continuous feeding conditions (Willason \& Cox 1987, Perissinotto 1992, Perissinotto \& Pakhomov 1996). The role of charcoal particles is to displace previously ingested food. The duration of these incubations ranged from $2-4 \mathrm{~h}$ for juveniles (length $=1.5$ to $2.5 \mathrm{~cm}$ ) to $12-24 \mathrm{~h}$ for adults (length = 4 to $5 \mathrm{~cm}$ ) and the decline in gut content was monitored at intervals of 10 to 15 min for the first hour and 1 to $4 \mathrm{~h}$ thereafter. Gut evacuation rates $\left(\mathrm{h}^{-1}\right)$ were derived from the slope of the regression of the natural logarithm of gut pigments versus time (Dam \& Peterson 1988). Altogether, 5 gut evacuation experiments were carried out along the transect, 3 with adults and 2 with juvenile krill.

Loss of pigments to non-fluorescent end-products by absorbtion/destruction was estimated at the $24 \mathrm{~h}$ station (WR-22) situated in the vicinity of the APF. Five independent measurements of pigment loss were made on this occasion. In each experiment, krill were first allowed to empty their gut of pigments for $24 \mathrm{~h}$ in filtered seawater with charcoal particles. Single individuals were then incubated for 1 to $2 \mathrm{~h}$ in $1 \mathrm{l}$ bottles with naturally occurring phytoplankton concentrations. A 2-compartment pigment budget approach was employed by comparing the decrease in pigment content of grazing bottles with the increase in gut pigment levels of krill incubated in these bottles (Lopez et al. 1988, Mayzaud \& Razouls 1992, Perissinotto 1992). Calculations of the fractional loss of pigment were made using the equation of Perissinotto (1992) and values were expressed as percent digestion efficiency. Krill daily ingestion rates ( $I$ ) were estimated from the relation (Wang \& Conover 1986, Perissinotto 1992):

$$
I=k G /\left(1-b^{\prime}\right)
$$

where $b^{\prime}$ is a non-dimensional index of the loss of pigment during digestion. As estimates of $k$ and $b^{\prime}$ were not available for all stations, average values for these parameters were used when no direct measurements were made. Also, when extrapolating hourly ingestion rates to daily rates, differences in feeding activity between dark and light periods were taken into account. Daytime levels were multiplied by an average of 2.03 (night/day ratio derived from the $24 \mathrm{~h}$ station) to derive nighttime rates.

The gut contents of adult krill from 6 stations along the SANAE-APF transect were analysed for identifiable items. As the main aim of this analysis was to test the hypothesis that krill would ingest a substantial proportion of zooplankton in the absence of a rich phytoplankton stock, only krill from north of $60^{\circ} \mathrm{S}$ ( Stn WR-13) to the southern edge of the APF (Stn WR-22) were selected. This is the area where the lowest chlorophyll a levels were recorded during the transect. Altogether, 28 guts from preserved krill were removed and the identifiable items in their contents counted under an inverted microscope at $400 \times$ magnification.

\section{RESULTS}

\section{Hydrology and phytoplankton production}

During January 1993, the presence of the APF was identified from salinity, and especially temperature profiles (Fig. 1; $2^{\circ} \mathrm{C}$ isotherm intersects the $200 \mathrm{~m}$ depth) at a latitude of $50^{\circ} 49^{\prime} \mathrm{S}$. The pack ice had retreated close to the continental shelf and its outer edge was located at a latitude of $69^{\circ} 10^{\prime} \mathrm{S}$. The seasonal marginal ice zone (MIZ) in this area usually attains its maximum winter expansion at a latitude of $\sim 60^{\circ} \mathrm{S}$ (Comiso et al. 1993). 
Fig. 1. Vertical distribution of (A) temperature and (B) salinity along the SANAE-APF transect during January 1993. SANAE: South African National Antarctic Expedition; APF: Antarctic Polar Front

Chlorophyll a concentration was highest at the edge of the pack ice (Stn WR-2; Fig 2), where a subsurface $(10 \mathrm{~m})$ maximum of $3.5 \mu \mathrm{g} \mathrm{l}^{-1}$ was recorded. To the north of this bloom, levels remained relatively high, 1.0 to $1.5 \mu \mathrm{g} \mathrm{l^{-1 }}$, as far as $\sim 60^{\circ} \mathrm{S}$ but dropped dramatically thereafter to $0.1-0.5 \mu \mathrm{g}$ $1^{-1}$ (Fig. 2). A sharp increase occurred when the APF was approached at $50^{\circ} \mathrm{S}$. Here, chlorophyll a concentrdtions attained again levels of $\sim 1.0 \mu \mathrm{g}$ $\mathrm{I}^{-1}$ (Fig. 2).

In terms of size and taxonomic composition, the relatively rich phytoplankton community south of $60^{\circ} \mathrm{S}$ was dominated by diatoms of the micro size class (Fig. 3). Here, chainforming Nitzschia spp., Fragilaria kerguelensis, Chaetoceros spp. and Corethron criophilum accounted for 57 to $87 \%$ of the total microphytoplankton (Table 1). In the region of the APF, where a second peak in phytoplankton biomass was recorded at Stns WR-26 to WR-30 (Figs. 2 \& 3), the nano size class accounted for the

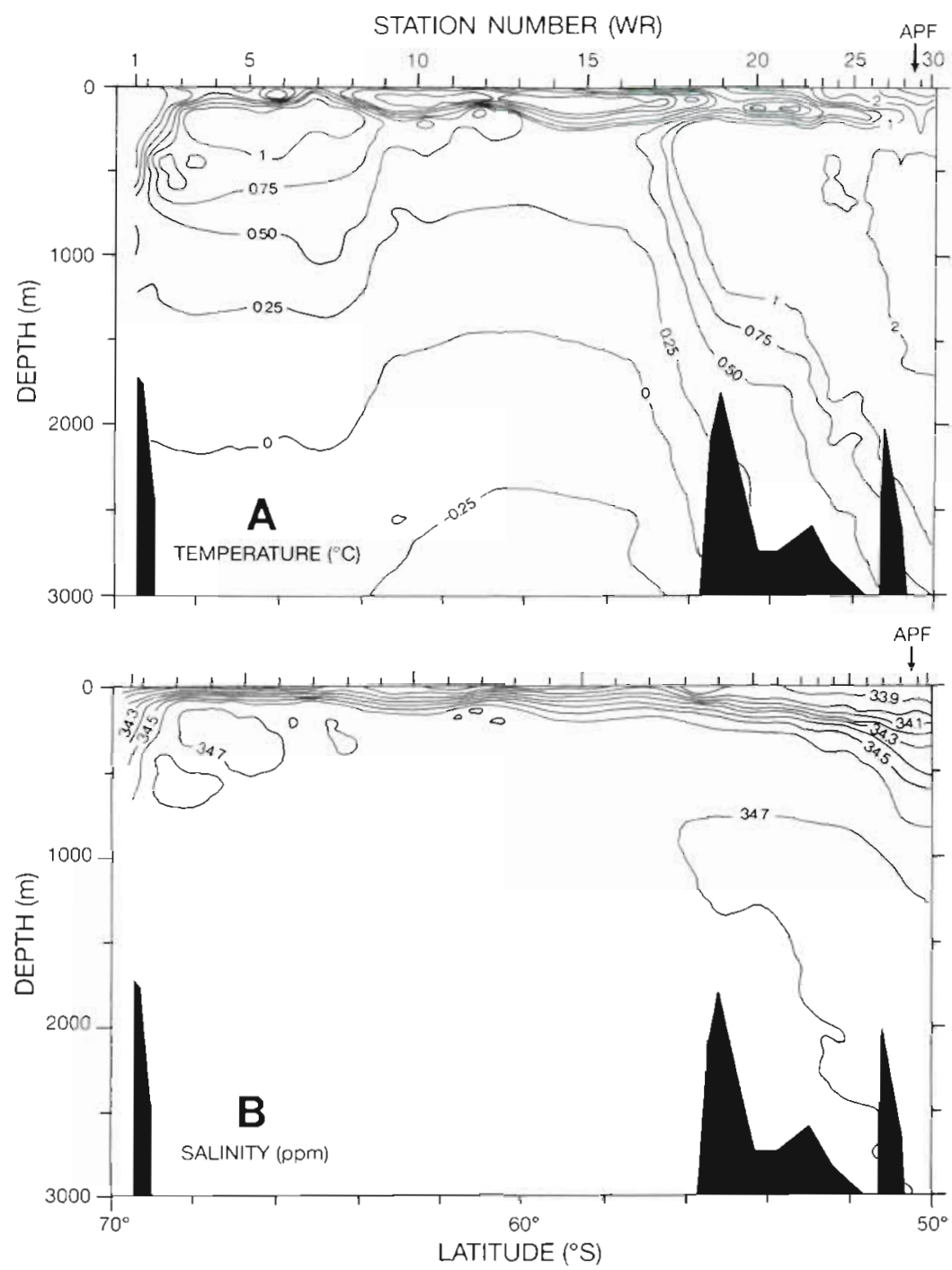

largest proportion of the total stock and Nitzschia spp. and C. criophilum constituted 65 to $87 \%$ of the microphytoplankton (Table 1). Between the APF and $60^{\circ} \mathrm{S}$, biomass was dominated at first by the pico (Stns WR-19 to WR-25) and then again by the nano size class (Stns WR-13 to WR-18; Fig. 3). In this area, Nitzschia spp. was generally still the largest contributor to microphytoplankton abundance but Chaetoceros spp., particularly $C$. dichaeta and $C$. criophilus, and Rhizosolenia alata $f$.

Fig. 2. Vertical distribution of chlorophyll a

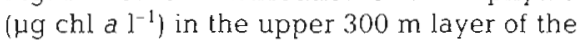
SANAE-APF transect, January 1993 
inermis and $R$. hebetata $f$. semispina were represented in much higher proportions than in the other areas. $C$. criophilus dominated the stock at Stns WR-20 to WR22 , with 69 to $84 \%$ of the total (Table 1).

Phytoplankton production rates were highest in the MIZ and at the APF, where daily levels integrated to the euphotic depth reached peaks of 500 to $1200 \mathrm{mg}$ $\mathrm{C} \mathrm{m}^{-2} \mathrm{~d}^{-1}$ (Laubscher et al. in press). Lowest rates were recorded in the area between the APF and $60^{\circ} \mathrm{S}$ ( $\leq 200 \mathrm{mg} \mathrm{C} \mathrm{m}^{-2} \mathrm{~d}^{-1}$ ), in conjunction with the lowest chlorophyll a concentrations and diatom abundances.

\section{Krill distribution and biomass}

Biomass and abundance levels derived from net tows ranged from minima of $\sim 50 \mathrm{mg}$ dry weight (DW) $\mathrm{m}^{-2}$ and $\sim 0.6$ ind $\mathrm{m}^{-2}$ to maxima of $\sim 6200 \mathrm{mg} \mathrm{DW} \mathrm{m} \mathrm{m}^{-2}$ and $\sim 110$ ind. $\mathrm{m}^{-2}$, respectively (Fig. 4). Highest levels occurred between $60^{\circ} \mathrm{S}$ and the $\mathrm{APF}$, and at the edge of the pack ice

Acoustic estimates of krill density were consistently higher than net estimates, although the distribution patterns derived from the 2 techniques were very similar (Fig. 4). Maximum levels of acoustic abundances were -400 ind $\mathrm{m}^{-2}$, i.e. 4 times higher than the figure obtained from the net tows, while minima were $\sim 10$ ind. $\mathrm{m}^{-2}$, i.e. 2 orders of magnitude higher than net estimates. Similarly, biomass levels derived from backscattering energy were 1.1 to 46.6 times (mean $=16.1 \pm 13.8 \mathrm{SD})$ higher than net estimates (Fig. 4). Maximum and minimum acoustic biomass

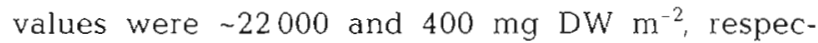
tively.

A diurnal rhythm in vertical migration was observed at the $24 \mathrm{~h}$ fixed station in the vicinity of the APF (Stn WR-22; Fig. 5A). Here, krill backscattering area $\left(S_{\mathrm{A}}\right)$ was most intense in the upper $25 \mathrm{~m}$ during nighttime ( 20:00 to 04:00 $\mathrm{h}$ GMT) but peaked in the 50 to $200 \mathrm{~m}$ depth layer during the day (Fig. 5A).

\section{Krill grazing dynamics}

Along the SANAE-APF transect, krill gut pigment content $(G)$ varied markedly, with highest levels recorded at the edge of the pack ice and in the vicinity of the APF (Fig. 6). In the pack ice, maximum individual $G$ values were $-10 \mu g$ chl a equiv. ind.-1, an order of magnitude higher than maxima elsewhere along the transect. The lowest gut pigment levels $(-10$ to $\left.20 \mathrm{ng} \mathrm{chl} \mathrm{a} \mathrm{equiv.} \mathrm{ind}{ }^{-1}\right)$ were found in the area of the seasonal advance and retreat of sea ice, between $60^{\circ}$ and $68^{\circ} \mathrm{S}$ (Fig. 6). Gut pigment content exhibited a clear spatial covariance $(p<0.05)$ with chlorophyll a concentration (both surface and depth-integrated), which accounted for -35 to $60 \%\left(\mathrm{r}^{2}\right)$ of its total variance. When considering the various size classes separately, microphytoplankton chlorophyll a concentralion explained the largest proportion (60.6\%) of the total variance associated with $G$. Generally, the highest average gut pigment levels were recorded at stations (Stns WR-2, WR-19, WR-20 and W-24) where microphytoplankton abundance was largely domi-
Fig. 3. Relative contribution of the micro-, nanoand picophytoplankton size classes to total chlorophyll a concentration in the surface layer $(\sim 5 \mathrm{~m})$ of the SANAEAPF transect, January 1993. PI: pack ice

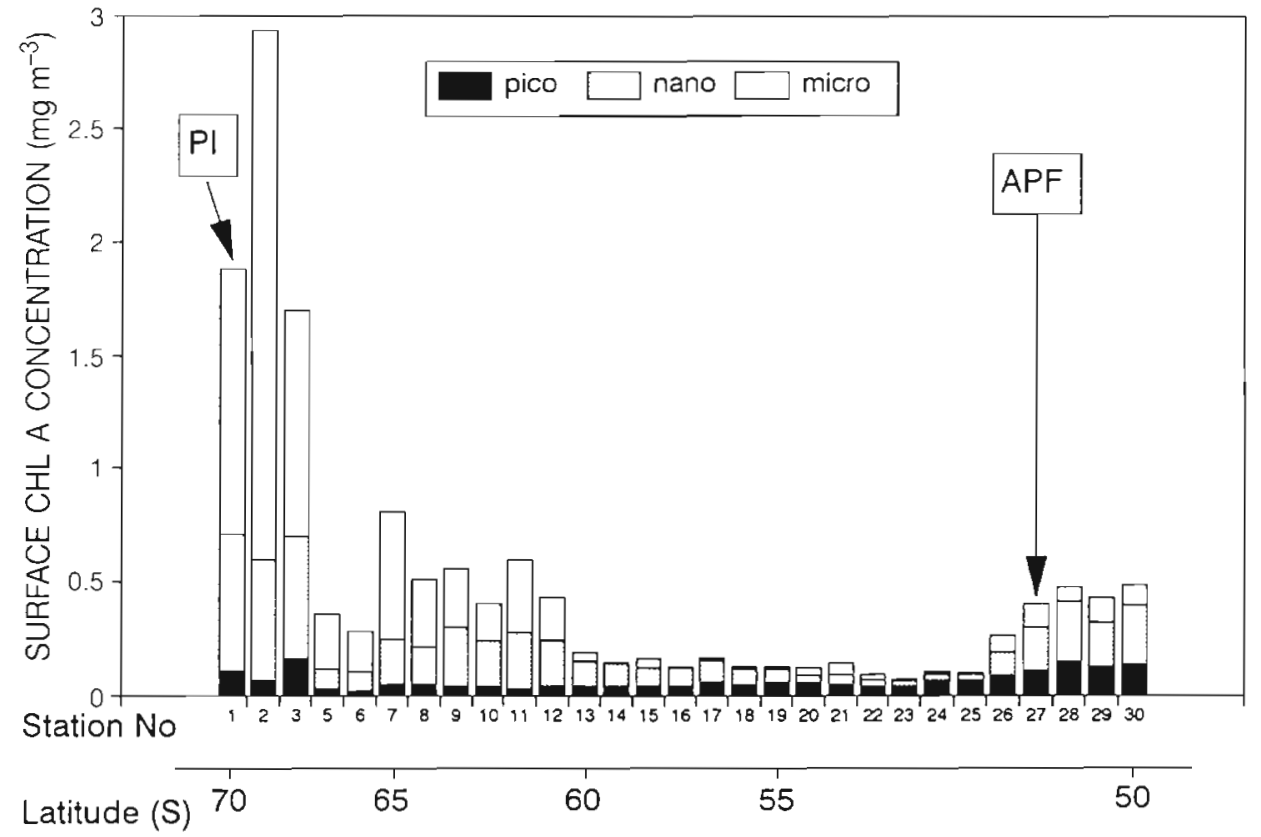


Table 1. Microphytoplankton $(\geq 20 \mu \mathrm{m})$ species composition and abundance south of the Antarctic Polar Front. Only species contributing $\geq 5 \%$ to the total stock are listed. C.f.: chain-forming. Abundances are expressed as $\times 10^{3} \mathrm{cellss}^{-1}$

\begin{tabular}{|c|c|c|c|c|}
\hline $\begin{array}{l}\text { Strn no. } \\
(W R)\end{array}$ & Lat. & $\begin{array}{l}\text { No. of } \\
\text { species }\end{array}$ & Abund. & Species composition and percent contribution \\
\hline 1 & $69^{\circ} 24^{\prime}$ & 30 & 21.2 & $\begin{array}{l}\text { Nitzschia sp. (c.f.) }(32 \%) \text {, Chaetoceros sp. }(17 \%) \text {, Eucampia antarctica }(10 \%) \text {, } \\
\text { Thalassiosira spp. }(9 \%) \text { Corethron criophilum }(8 \%)\end{array}$ \\
\hline 2 & $69^{\circ} 09^{\prime}$ & 22 & 15.0 & Nitzschia sp. (c.f.) (47\%), Corethron criophilum (36\%) \\
\hline 3 & $68^{\circ} 19^{\prime}$ & 27 & 38.8 & $\begin{array}{l}\text { Nitzschia sp. (c.f.) }(63 \%) \text {, Chaetoceros dichaeta (15\%), } \\
\text { Thalassiothrix longissima } v \text {. antarctica }(5 \%)\end{array}$ \\
\hline 4 & $67^{\circ} 30^{\prime}$ & 25 & 12.2 & $\begin{array}{l}\text { Chaetoceros dichaeta ( } 37 \%) \text {, Nitzschia sp. (c.f.) }(15 \%) \text {, Corethron criophilum }(9 \%) \text {, } \\
\text { Nitzschia seriata gr. }(7 \%) \text {, Chaetoceros criophilus }(6 \%)\end{array}$ \\
\hline 5 & $66^{\circ} 40^{\prime}$ & 23 & 11.9 & Chaetoceros dichaeta $(39 \%)$, Corethron criophilum $(20 \%)$, Chaetoceros flexuosus (17\%) \\
\hline 6 & $65^{\circ} 50^{\prime}$ & 28 & 14.2 & $\begin{array}{l}\text { Nitzschia sp. (c.f.) }(58 \%) \text {, Chaetoceros dichaeta }(14 \%) \\
\text { Rhizosolenia hebetata } f \text {. semispina }(5 \%)\end{array}$ \\
\hline 7 & $65^{\circ} 00^{\prime}$ & 30 & 51.0 & $\begin{array}{l}\text { Nitzschia sp. (c.f.) (45\%), Fragilaria kerguelensis (14\%), Chaetoceros dichaeta (12\%), } \\
\text { Corethron criophilum }(7 \%) \text {, Chaetoceros atlanticus }(5 \%)\end{array}$ \\
\hline 8 & $64^{\circ} 10^{\prime}$ & 24 & 57.6 & Nitzschia sp. (c.f.) (44\%), Fragilaria kerguelensis (43\%) \\
\hline 9 & $63^{\circ} 20^{\prime}$ & 35 & 10.7 & $\begin{array}{l}\text { Nitzschia sp. (c.f.) }(50 \%) \text {, Asteromphalus heptactis (10\%), Fragilaria kerguelensis }(8 \%) \text {, } \\
\text { Rhizosolenia hebetata } \mathrm{f} \text {. semispina }(5 \%)\end{array}$ \\
\hline 10 & $62^{\circ} 30^{\prime}$ & 26 & 17.1 & $\begin{array}{l}\text { Nitzschia sp. (c.f.) (46\%), Guinardia flaccida (34\%), Fragilaria kerguelensis (13\%), } \\
\text { Asteromphalus heptactis }(5 \%)\end{array}$ \\
\hline 11 & $61^{\circ} 39^{\prime}$ & 29 & 31.2 & Nitzschia sp. (c.f.) (61\%), Chaetoceros flexuosus (7\%), Fragilaria kerguelensis $(7 \%)$ \\
\hline 12 & $60^{\circ} 50^{\prime}$ & 28 & 20.1 & $\begin{array}{l}\text { Nitzschia sp. (c.f.) }(35 \%) \text {, Chaetoceros dichaeta (23\%), Guinardia flaccida }(7 \%) \text {, } \\
\text { Nitzschia closterium }(5 \%)\end{array}$ \\
\hline 13 & $60^{\circ} 00^{\prime}$ & 30 & 10.6 & $\begin{array}{l}\text { Nitzschia sp. (c.f.) (41\%), Guinardia flaccida (12\%), Chaetoceros dichaeta }(11 \%) \text {, } \\
\text { Fragilaria kerguelensis }(5 \%) \text {, Chaetoceros crophilus }(5 \%)\end{array}$ \\
\hline 14 & $59^{\circ} 10^{\prime}$ & 27 & 4.91 & $\begin{array}{l}\text { Nitzschia sp. (c.f.) }(48 \%) \text {, Rhizosolenia alata f. inermis }(10 \%) \text {, Chaetoceros dichaeta }(7 \%) \text {, } \\
\text { Asteromphalus heptactis (5\%), Chaetoceros criophilus }(5 \%)\end{array}$ \\
\hline 15 & $58^{\circ} 20^{\prime}$ & 26 & 3.19 & $\begin{array}{l}\text { Nitzschia sp. (c.f.) (31\%), Rhizosolenia alata f. inermis (20\%), Chaetoceros dichaeta }(8 \%) \text {, } \\
\text { Chaetoceros criophilum }(6 \%) \text {. Asteromphalus heptactis }(6 \%) \text {, Thalassiosira spp. }(6 \%)\end{array}$ \\
\hline 16 & $57^{\circ} 30^{\prime}$ & 25 & 2.13 & $\begin{array}{l}\text { Nitzschia sp. (c.f.) }(43 \%), \text { Rhizosolenia alata f. inermis }(20 \%) \text {, Chaetoceros criophilus }(10 \%) \text {, } \\
\text { Chaetoceros dichaeta }(6 \%)\end{array}$ \\
\hline 17 & $56^{\circ} 40^{\prime}$ & 22 & 2.03 & Nitzschia sp. (c.f.) (42\%), Rhizosolenia alata f. inermis (25\%), Rhizosolenia alata (6\%) \\
\hline 18 & $55^{\circ} 50^{\prime}$ & 19 & 0.72 & $\begin{array}{l}\text { Nitzschia sp. (c.f.) }(41 \%) \text {, Chaetoceros criophilus ( } 24 \%) \text {, Rhizosolenia alata f. inermis }(9 \%) \text {, } \\
\text { Chaetoceros dichaeta }(5 \%) \text {, Thalassiosira antarctica }(5 \%)\end{array}$ \\
\hline 19 & $55^{\circ} 00^{\prime}$ & 19 & 0.81 & $\begin{array}{l}\text { Nitzschia sp. (c.f.) (57\%), Chaetoceros criophilus (16\%), Thalassiosira spp. }(5 \%) \text {, } \\
\text { Corethron criophilum }(5 \%)\end{array}$ \\
\hline 20 & $54^{\circ} 10^{\prime}$ & 16 & 1.65 & Chaetoceros criophilus $(69 \%)$, Nitzschia sp. (c.f.) $(10 \%)$ \\
\hline 21 & $53^{\circ} 35^{\prime}$ & 13 & 1.95 & $\begin{array}{l}\text { Chaetoceros criophilus }(69 \%) \text {. Nitzschia sp. (c.f.) }(7 \%) \text {. Rhizosolenia alata f. inermis }(5 \%) \text {, } \\
\text { Chaetoceros dichaeta }(5 \%)\end{array}$ \\
\hline 22 & $52^{\circ} 59^{\prime}$ & 10 & 2.31 & Chaetoceros crophilus (84\%), Nitzschia sp. (c.f.) $(5 \%)$ \\
\hline 23 & $52^{\circ} 34^{\prime}$ & 20 & 0.43 & Nitzschia sp. (c.f.) $(76 \%)$, Chaetoceros criophilus (14\%) \\
\hline 24 & $52^{\circ} 10^{\prime}$ & 17 & 0.48 & Nitzschia sp. (c.f.) $(74 \%)$, Rhizosolenia hebetata f. semispina $(12 \%)$ \\
\hline 25 & $51^{\circ} 45^{\prime}$ & 16 & 0.48 & $\begin{array}{l}\text { Nitzschia sp. (c.f.) }(65 \%) \text {, Rhizosolenia hebetata f. semispina }(17 \%) \text {, } \\
\text { Rhizosolenia alata f. inermis }(8 \%)\end{array}$ \\
\hline 26 & $51^{\circ} 20^{\prime}$ & 32 & 1.37 & Nitzschia sp. (c.f.) $(63 \%)$, Corethron criophilum (6\%) \\
\hline 27 & $50^{\circ} 56^{\prime}$ & 26 & 4.73 & $\begin{array}{l}\text { Nitzschia sp. (c.f.) }(45 \%) \text {, Corethron criophilum }(24 \%) \text {, Chaetoceros peruvianus }(11 \%) \text {, } \\
\text { Chaetoceros dichaeta }(6 \%)\end{array}$ \\
\hline 28 & $50^{\circ} 30^{\prime}$ & 20 & 9.00 & Nitzschia sp. (c.f.) (75\%), Corethron criophilum (12\%) \\
\hline 29 & $50^{\circ} 06^{\prime}$ & 27 & 3.15 & $\begin{array}{l}\text { Nitzschia sp. (c.f.) }(43 \%), \text { Corethron criophilum }(22 \%) \text {, Chaetoceros peruvianus }(5 \%) \text {, } \\
\text { Nitzschia seriata gr. }(5 \%)\end{array}$ \\
\hline 30 & $49^{\circ} 4 I^{\prime}$ & 23 & 3.48 & $\begin{array}{l}\text { Nitzschia sp. (c.f.) }(39 \%) \text {, Corethron criophilum (33\%), Rhizosolenia alata f. inermis (5\%), } \\
\text { Nitzschia seriata gr. }(5 \%)\end{array}$ \\
\hline
\end{tabular}




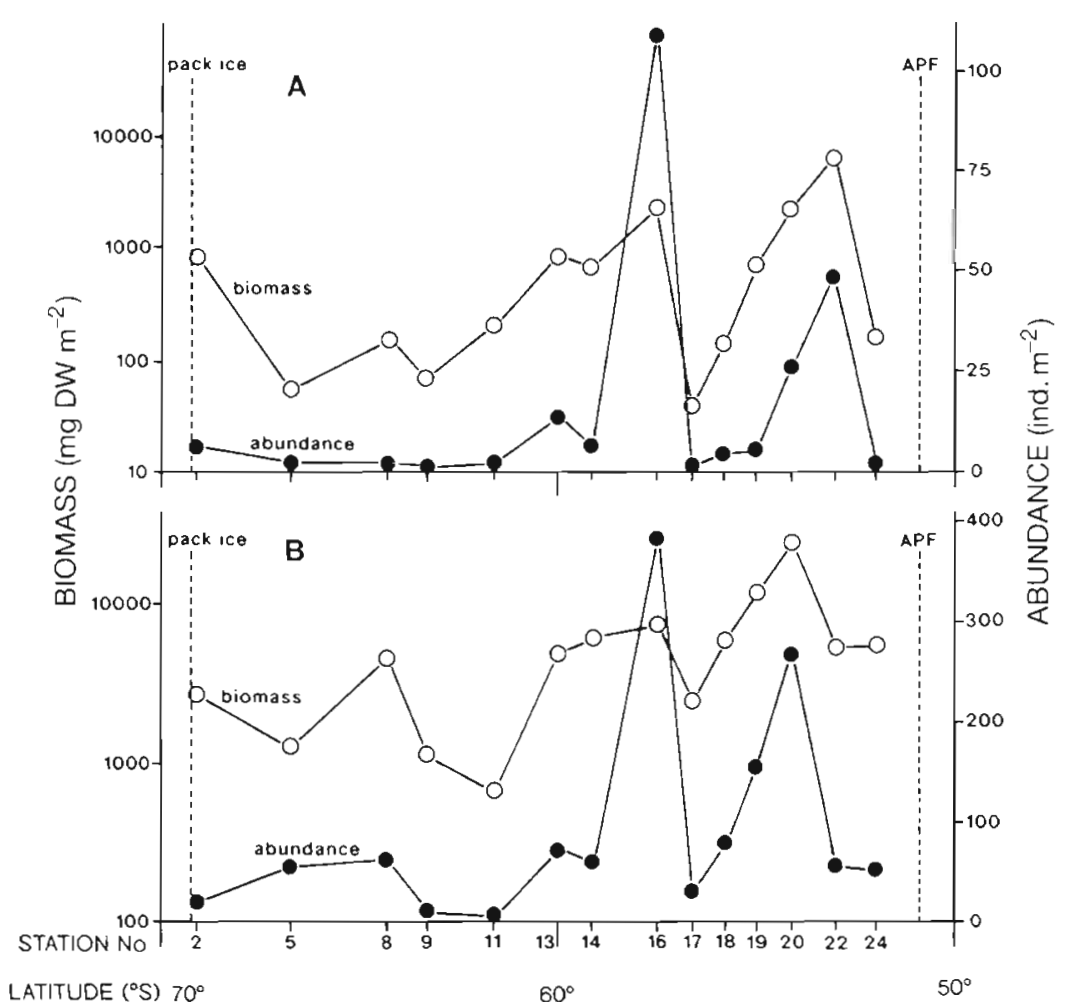

Fig. 4. Euphausia superba. Estimates of krill abundance and biomass along the SANAE-APF transect obtained from (A) RMT-8/Bongo net tows and from (B) $120 \mathrm{kHz}$ acoustic backscattering intensity
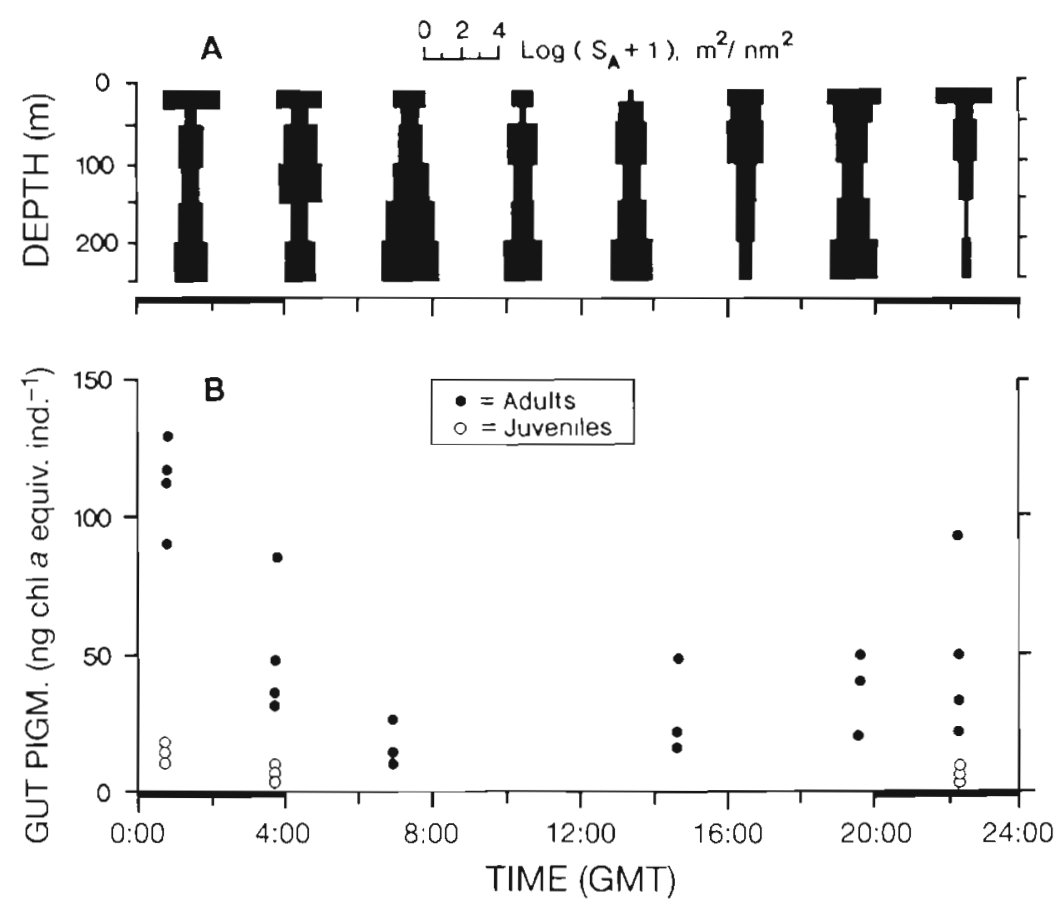

Fig. 5. Euphausia superba. Relationship between krill diurnal migrations as derived from (A) acoustic data and (B) gut pigment contents at Stn WR-22, to the south of the APF (28-29 January 1993) nated by 2 groups of diatoms: chainforming Nitzschia spp. and Corethron criophilum (Table 1). It must be pointed out, however, that microphytoplankton abundances at these stations were among the lowest of the transect. On the other hand, stations with the lowest krill gut contents were often dominated by Chaetoceros dichaeta (Stn WR-5) or Chaeotoceros criophilus (Stn WR-22), or had a substantial proportion of Chaetoceros spp. and Rhizosolenia spp. cells (>25\%, Stns WR-14 and WR-18; Table 1). Diurnal variations in gut pigments were monitored at the $24 \mathrm{~h}$ station (Stn WR-22, Fig. 5B). For adults, the pattern observed was the same as for krill vertical migration. Mean nighttime $G$ levels $(63.5 \pm 39.2 \mathrm{SD})$ were $\sim 2$ times higher than daytime ones $(31.3 \pm$ 11.5 SD), although no statistical differences were found between the 2 periods $(t$-test, $p>0.05)$. No data were available for juveniles during the day.

In all 5 gut evacuation experiments a negative exponential model provided the best fit to the decline in gut pigment content over time (Fig. 7). Gut evacuation rates, $k$, ranged from 0.10 to $0.17 \mathrm{~h}^{-1}$ in adult krill $(\sim 4.5 \mathrm{~cm}$ length) and from 0.22 to $0.31 \mathrm{~h}^{-1}$ in juveniles ( 2 cm length) (Table 2). The corresponding gut turnover times, $1 / k$, were, therefore, 5.9 to $9.9 \mathrm{~h}$ for adults (Fig. 7A) and 3.2 to $4.5 \mathrm{~h}$ for juveniles (Fig. 7B). Neither $k$ nor $1 / k$ appeared to be related to in situ chlorophyll $a$ concentration but both parameters covaried with the initial gut pigment content in the case of both adults and juveniles (Table 2).

Levels of gut pigment degradation were very high and -67 to $90 \%$ of the total pigment ingested by krill was not recovered in their guts (Table 3). An average factor of 0.191 (i.e. $1-b^{\prime}$ ) of degradation efficiency was, therefore, used in the calculation of ingestion rates, $I$.

Individual ingestion rates were highest at the edge of the pack ice $(-90 \mu \mathrm{g}$ chl a equiv. ind ${ }^{-1} \mathrm{~d}^{-1}$ ) and just to the south of the APF, between $52^{\circ}$ and $55^{\circ} \mathrm{S}$ ( 2 to $3 \mu \mathrm{g}$ chl a equiv. ind.$^{-1} \mathrm{~d}^{-1}$; Fig. $6 \mathrm{~B}$ ). Lowest rates were again recorded in 


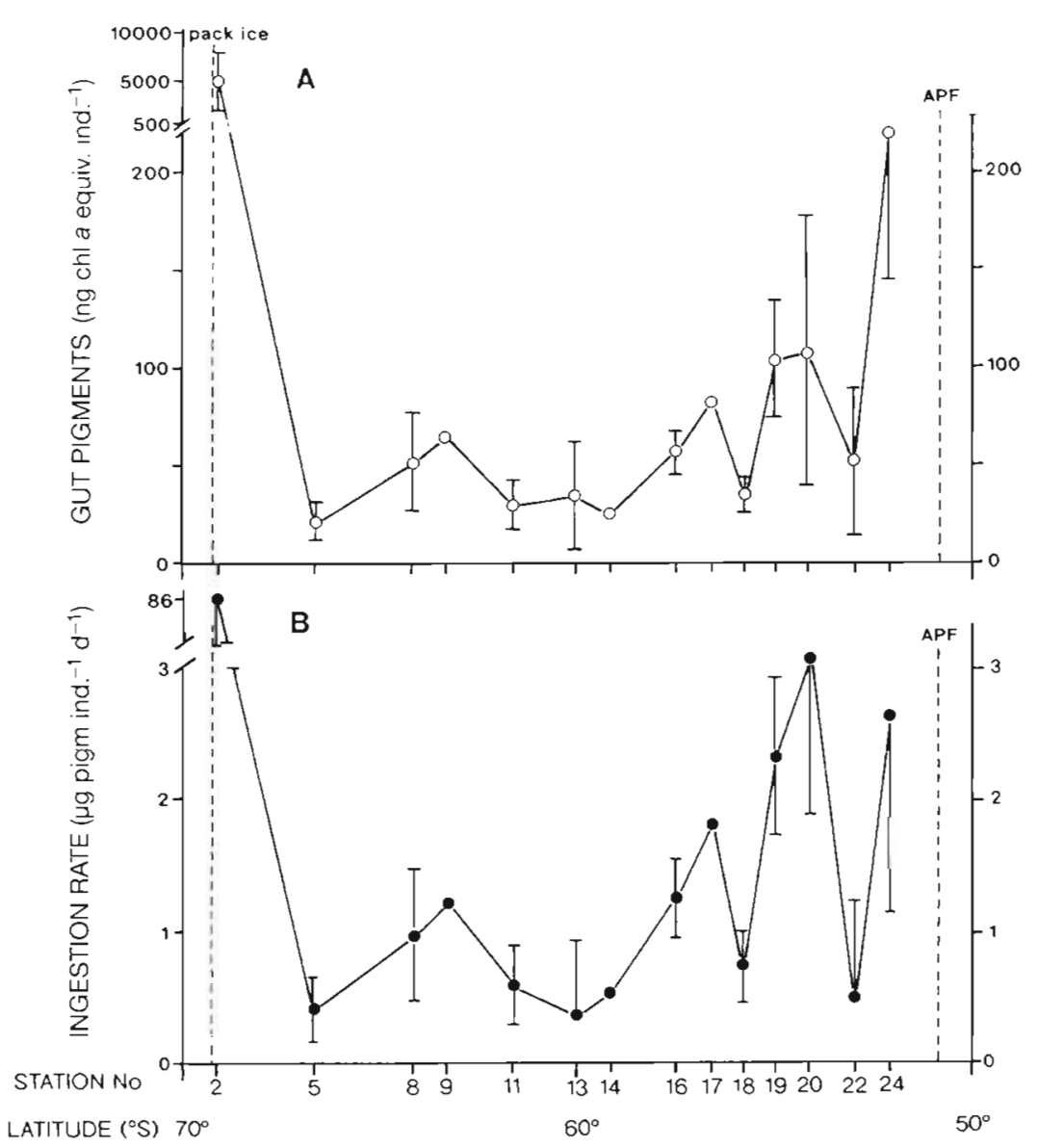

Fig. 6. Euphausia superba. Spatial distribution of krill (A) gut pigment content and $(B)$ ingestion rates along the SANAE-APF transect during January 1993 Error bars represent standard deviations from the mean a concentration into autotrophic carbon, the range of daily carbon consumption was estimated at $\sim 0.1$ to $30 \mathrm{mg} \mathrm{C} \mathrm{d} \mathrm{d}^{-1}$ (Table 4). These rates are equivalent to $0.0014-0.42 \%$ of total $300 \mathrm{~m}$ integrated chlorophyll a and $0.023-14.4 \%$ of primary production consumed per day (Table 4). However, when krill biomass levels derived from acoustic backscattering energy rather than net tows were considered, population grazing impact varied from $\sim 5$ to $1600 \mu \mathrm{g}$ chl a equiv. $\mathrm{d}^{-1}$, or from $\sim 0.5$ to $150 \mathrm{mg} \mathrm{C} \mathrm{d}^{-1}$ (Table 4). These are equivalent to consumption rates of 0.01 to $2.68 \%$ and 0.45 to $50.8 \%$ of the total chlorophyll $a$ and primary production, respectively.

The main food items that could be identified in the gut contents of adult krill were subdivided in 4 groups: microphytoplankton, microzooplankton, mesozooplankton fragments and round bodies of unknown origin (Table 5). With 1 exception (Stn WR-19), microphytoplankton cells and chains dominated gut contents, accounting for 35 to $65 \%$ of the total number of recognizable particles. The most important taxa in this group were Nitzschia spp., Fragilaria kerguelensis and Thalassiosira spp., while taxa such as Chaetoceros spp. and Rhizosolenia spp., which often dominated the microphytoplankton the region of the seasonal ice retreat, from $59^{\circ}$ to $67^{\circ} \mathrm{S}$, where on average krill ingested $1 \mu \mathrm{g}$ chl a equiv. ind ${ }^{-1}$ $\mathrm{d}^{-1}$. When extrapolated to the entire krill population estimated from net tows, the grazing impact of Euphausia superba ranged from a minimum value of $<1 \mu \mathrm{g}$ chl a equiv. $\mathrm{d}^{-1}$ at Stn WR-9 to a maximum of $\sim 570 \mu \mathrm{g}$ chl a equiv. $\mathrm{d}^{-1}$ at Stn WR-2 at the edge of the pack ice (Table 4). Using the empirical equation of Hewes et al. (1990), $\mathrm{C}=80 \mathrm{chl}^{0.6}$, to convert chlorophyll stock in the water column (Table 1), were almost absent from krill guts. Microzooplankton, particularly aloricate ciliates, were also very abundant, constituting $\sim 18$ to $47 \%$ of the total identifiable fraction, and even dominated in krill guts from Stn WR-19 (Table 5). Mesozooplankton fragments accounted for only -11 to $31 \%$ of total particles by number, but many of them were very large and represented a substantial proportion of the total volume of material ingested.

Table 2. Euphausia superba. Gut clearance parameters for juvenile and adult krill and their relationships with ambient chlorophyll a (chl a) concentration and initial gut pigment content, $G\left(t_{0}\right)$. Chl a values were integrated over the upper $300 \mathrm{~m}$ layer

\begin{tabular}{|c|c|c|c|c|c|c|}
\hline $\begin{array}{l}\text { Krill } \\
\text { stage }\end{array}$ & $\begin{array}{l}\text { Stn } \\
\text { no. }\end{array}$ & $\begin{array}{l}\text { Time } \\
\text { (GMT) }\end{array}$ & $\begin{array}{c}\text { Gut evacuation } \\
\qquad k\left(\mathrm{~h}^{-1}\right)\end{array}$ & $\begin{array}{c}\text { Gut turnover } \\
1 / k(\mathrm{~h})\end{array}$ & $\begin{array}{c}\text { Initial chl a } \\
\left(\mathrm{mg} \mathrm{chl} \mathrm{m}^{-2} \text { ) }\right.\end{array}$ & $\begin{array}{c}G\left(t_{0}\right) \\
\left.\text { (ng chl } a \text { equiv. ind. }{ }^{-1}\right)\end{array}$ \\
\hline $\begin{array}{l}\text { Adults } \\
(4-5 \mathrm{~cm})\end{array}$ & $\begin{array}{c}\text { WR-14 } \\
\text { WR-20 } \\
\text { WR-22/7 }\end{array}$ & $\begin{array}{l}10: 39 \mathrm{~h} \\
15: 21 \mathrm{~h} \\
22: 09 \mathrm{~h}\end{array}$ & $\begin{array}{l}0.126 \\
0.170 \\
0.101\end{array}$ & $\begin{array}{l}7.94 \\
5.87 \\
9.88\end{array}$ & $\begin{array}{l}36.9 \\
30.7 \\
25.7\end{array}$ & $\begin{array}{c}64.34 \\
107.02 \\
48.40\end{array}$ \\
\hline $\begin{array}{l}\text { Juveniles } \\
(1.5-2.5 \mathrm{~cm})\end{array}$ & $\begin{array}{l}\text { WR-16 } \\
\text { WR-22/8 }\end{array}$ & $\begin{array}{l}08: 21 \mathrm{~h} \\
00: 40 \mathrm{~h}\end{array}$ & $\begin{array}{l}0.308 \\
0.220\end{array}$ & $\begin{array}{l}3.24 \\
4.55\end{array}$ & $\begin{array}{l}33.0 \\
25.5\end{array}$ & $\begin{array}{l}57.72 \\
12.65\end{array}$ \\
\hline
\end{tabular}




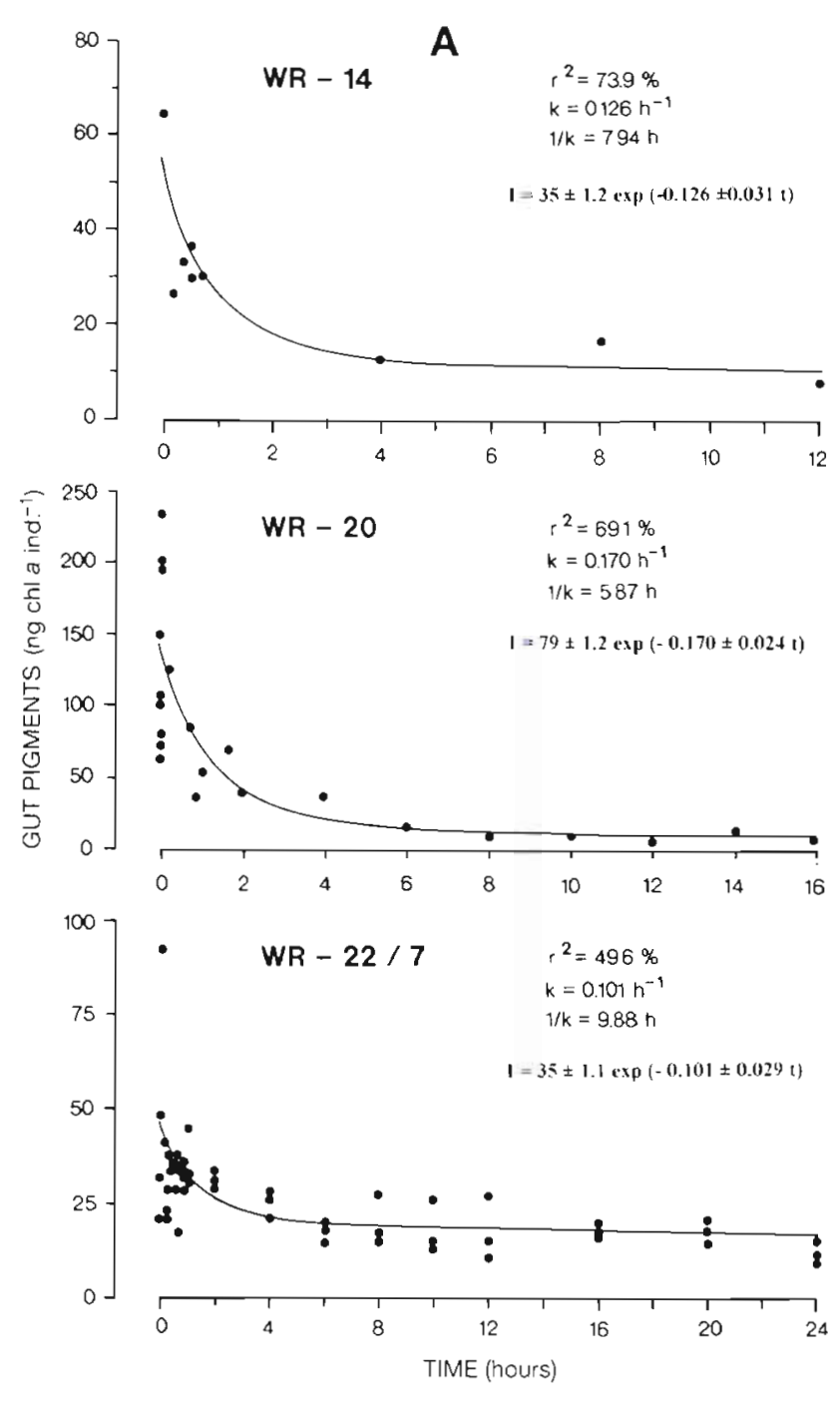

DISCUSSION

The adaptation of the gut fluorescence technique (Mackas \& Bohrer 1976) used in this study provides a rapid and simple method for measuring in situ grazing rates of krill on the phytoplankton stock. When applying this method, there are usually 2 major problems

Table 3. Euphausıa superba. Estimation of the digestion efficiency for adult krill collected at Stn WR-22 in the vicinity of the Antarctic Polar Front (28-29 January 1993)

\begin{tabular}{|c|c|c|c|}
\hline $\begin{array}{l}\text { Exp } \\
\text { no. }\end{array}$ & $\begin{array}{l}\text { Pigment ingested } \\
\text { (ng chl } a \text { equiv. ind. }{ }^{-1} \text { ) }\end{array}$ & $\begin{array}{l}\text { Pigment recovered } \\
\text { (ng chl a equiv. ind } .^{-1} \text { ) }\end{array}$ & $\begin{array}{c}\text { Digestion } \\
\text { efficiency }(\%)\end{array}$ \\
\hline 1 & $33.6 \pm 4.06$ & $3.33 \pm 2.15$ & $90.1 \pm 6.39$ \\
\hline 2 & $24.2 \pm 4.24$ & $4.15 \pm 0.29$ & $82.9 \pm 1.20$ \\
\hline 3 & $25.2 \pm 3.53$ & $5.97 \pm 3.10$ & $76.4 \pm 12.3$ \\
\hline 4 & $36.1 \pm 3.36$ & $4.36 \pm 0.94$ & $87.9 \pm 2.61$ \\
\hline 5 & $27.9 \pm 5.13$ & $9.18 \pm 1.14$ & $67.0 \pm 4.09$ \\
\hline
\end{tabular}

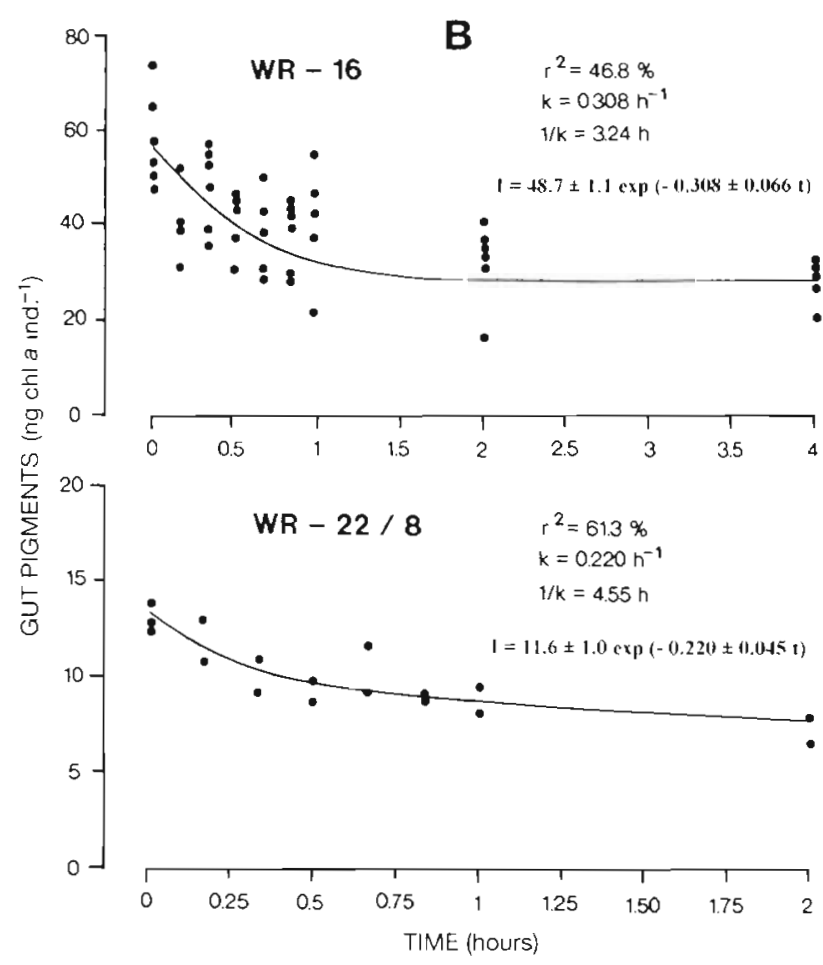

Fig. 7. Euphausia superba. Dynamics of gut evacuation in (A) adult and (B) juvenile krill under continuous feeding conditions $(<100 \mu \mathrm{m}$ charcoal particles suspended in filtered seawater). $k$ : gut evacuation rates; 1 : krill daily ingestion rates

that may severely affect the calculation of individual rates and population impact. These are related to an accurate determination of the gut clearance rate (Dagg \& Grill 1980, Huntley et al. 1987, Penry \& Frost 1990, Tseytlin et al. 1991) and the level of gut pigment degradation to non-fluorescent end products (Conover et al. 1986, Kiørboe \& Tiselius 1987, Lopez et al. 1988, Head 1992, Mayzaud \& Razouls 1992).

The gut clearance rate $(k)$ and its inverse value, the gut turnover time $(1 / k)$, are usually determined as loss of gut pigments after the transfer of previously feeding krill to filtered seawater. This is based on the assumption that starvation does not dramatically affect the dynamics of gut evacuation. The assumption is reasonable for copepods, at least during short-term incubations (Ellis \& Small 1989, Peterson et al. 1990). However, evacuation rates can be substantially 
Table 4. Euphausia superba. Daily estimates of chlorophyll and autotrophic carbon consumption by the krill population along the SANAE-APF transect. Chl-Ing and C-Ing represent the rates of chlorophyll a (chl a) and carbon ingestion, respectively. Estimates of krill biomass were derived both from data of net tows $(N)$ and from acoustic backscattering $(A)$

\begin{tabular}{|c|c|c|c|c|c|c|c|c|c|}
\hline Stn no. & $\begin{array}{c}\text { Chl-Ing }(\mathrm{N}) \\
\left(\mu \mathrm{g} \text { chl a equiv. } \mathrm{d}^{-1}\right)\end{array}$ & $\begin{array}{c}\text { Chl-Ing }(A) \\
\left(\mu g \text { chl a equiv. } d^{-1}\right)\end{array}$ & $\begin{array}{l}\mathrm{C}-\operatorname{Ing}(\mathrm{N}) \\
\left(\mathrm{mg} C \mathrm{~d}^{-1}\right)\end{array}$ & $\begin{array}{l}\text { C-Ing }(\mathrm{A}) \\
\left(\mathrm{mg} \mathrm{C} \mathrm{d}^{-1}\right)\end{array}$ & $\begin{array}{c}(\mathrm{N}) /(\mathrm{A}) \\
(\%)\end{array}$ & $\begin{array}{l}\% \text { chl } a \\
(\mathrm{~N})\end{array}$ & $\begin{array}{l}\% \operatorname{chl} a \\
\text { (A) }\end{array}$ & $\begin{array}{l}\% \text { prod. } \\
(\mathrm{N})\end{array}$ & $\begin{array}{l}\% \text { prod } \\
\text { (A) }\end{array}$ \\
\hline WR-2 & 573.8 & 1619 & 29.81 & 84.14 & 35.43 & 0.281 & 0.871 & No data & No data \\
\hline WR-5 & 1.03 & 23.38 & 0.124 & 2.802 & 4.405 & 0.001 & 0.032 & 0.023 & 0.455 \\
\hline WR-8 & 2.24 & 59.08 & 0.233 & 6.145 & 3.791 & 0.005 & 0.133 & No data & No data \\
\hline WR-9 & 0.87 & 14.68 & 0.088 & 1.479 & 5.926 & 0.002 & 0.028 & No data & No data \\
\hline WR-11 & 1.53 & 5.35 & 0.149 & 0.522 & 28.59 & 0.003 & 0.010 & No data & No data \\
\hline WR-13 & 4.98 & 26.71 & 0.790 & 4.235 & 18.64 & 0.014 & 0.075 & No data & No data \\
\hline WR-1.4 & 3.75 & 32.21 & 0.664 & 5.703 & 11.64 & 0.01 .0 & 0.087 & 0.294 & 2.532 \\
\hline WR-16 & 139.2 & 489.8 & 24.73 & 87.04 & 28.42 & 0.420 & 1.484 & 14.42 & 50.76 \\
\hline WR-1? & 1.09 & 53.96 & 0.172 & 8.497 & 2.020 & 0.003 & 0.159 & No data & No data \\
\hline WR-18 & 4.04 & 62.40 & 0.759 & 11.74 & 6.474 & 0.009 & 0.275 & 0.490 & 6.505 \\
\hline WR-19 & 13.94 & 362.7 & 2.485 & 64.64 & 3.843 & 0.087 & 1.246 & No data & No data \\
\hline WR-20 & 80.76 & 823.3 & 14.70 & 149.9 & 9.809 & 0.262 & 2.682 & No data & No data \\
\hline WR-22 & 25.10 & 28.13 & 5.109 & 5.726 & 89.23 & 0.127 & 0.112 & 2.280 & 1.940 \\
\hline WR-24 & 4.76 & 1433 & 0.934 & 28.13 & 3.324 & 0.018 & 0.555 & No data & No data \\
\hline
\end{tabular}

underestimated in the case of non-feeding euphausiids as these tend to retain food in their guts for long periods. up to $2 \mathrm{~d}$ (Willason \& Cox 1987). Thus, our incubations to determine the gut evacuation rate of Euphausia superba were carried out in filtered seawater to which non-fluorescent charcoal particles had been added, in concentrations equivalent to the ambient seston wet weight (Perissinotto \& Pakhomov 1996).

The other important factor to take into account in the calculation of krill grazing rates is the loss of fluorescing pigments during digestion. Losses may range from 1 to $99 \%$ of the total pigment ingested (Conover et al. 1986, Kiørboe \& Tiselius 1987) and may be affected by ambient food concentrations and digestive acclimation processes (Mayzaud \& Razouls 1992). Our experimental protocol involved a series of 5 replicated measurements of in situ gut pigment degradation, or digestion efficiency, of Euphausia superba. The values obtained were consistently high, with 67 to $90 \%$ degradation levels, indicating that grazing rates obtained from gut pigment concentrations which are not corrected for digestive losses may be underestimated by nearly 1 order of magnitude.

The estimates of individual grazing rates presented in this study are, therefore, among the most realistic obtained to date, as they incorporate all the major variables affecting the measurement of krill grazing in situ (Quetin et al. 1987, Daly 1990, Priddle et al. 1990), i.e. gut pigment content, gut evacuation rate and digestion efficiency. However, when scaling up to the impact of the summer krill population on the total phytoplankton stock (Table 4), the figures obtained are largely dependent on the accuracy of the abundance estimates. In this respect, it is worth recalling that the estimates of daily phytoplankton consumption by krill obtained using net abundance data are up to 2 orders of magnitude lower than those obtained using acoustic data (Table 4). This difference is probably due to net avoidance by krill, which is particularly effective in daylight conditions (Holm-Hansen \& Huntley 1984, Mathew 1988, Nordhausen 1994). It is now widely accepted that net catches can only provide some lower limits on the abundance of krill (Miller \& Hampton 1989). On the other hand, recent developments in the use of acoustic backscattering, and in particular the refinement of the target-strength and temperature calibrations, have dramatically improved the quality of abundance data obtained from this source (Everson et al. 1990, Greene et al. 1991, Hewitt \& Demer 1991).

The individual rates of phytoplankton consumption obtained for krill in this study range from a minimum of 0.37 to a maximum of $86 \mu \mathrm{g}$ chl a equiv. ind. ${ }^{-1} \mathrm{~d}^{-1}$ (or 0.05 to $4.45 \mathrm{mg} \mathrm{C}$ ind. ${ }^{-1} \mathrm{~d}^{-1}$ ). When the results of previous feeding studies are standardized to the same units, the ingestion rates estimated from our in situ approach are generally 1.5 to 3 times higher than those obtained with in vitro incubations (Antezana et al. 1982, Meyer \& El Sayed 1983, Schnack 1985, Price et al. 1988) and within the range of values obtained by Quetin et al. (1987) and by Pakhomov et al. (1997) with their adaptation of the gut fluorescence technique. This has important implications for carbon cycling in the Southern Ocean and for the energy budget of the Antarctic krill.

On a meso- and macroscale, only a minor portion $(<10 \%)$ of the total phytoplankton production of the Southern Ocean is generally considered to be directly channelled to Antarctic krill by grazing (Holm-Hansen \& Huntley 1984, Drits \& Semenova 1989, Drits \& Pasternak 1993). Only occasionally, and in the pres- 
Table 5. Euphausia superba. Average abundances of identifiable tems in the gut contents of krill at stations along the SANAEAPF transect of January 1993. Values in parentheses represent standard error of the mean

\begin{tabular}{|c|c|c|c|c|c|c|}
\hline Food item & $\begin{array}{l}W R-13 \\
(n=5)\end{array}$ & $\begin{array}{l}\text { WR-14 } \\
(\mathrm{n}=3)\end{array}$ & $\begin{array}{l}\text { WR-16 } \\
(n=5]\end{array}$ & $\begin{array}{l}\text { WR-19 } \\
(n=5)\end{array}$ & $\begin{array}{l}\text { WR-20 } \\
(n=5)\end{array}$ & $\begin{array}{l}\text { WR-22 } \\
(\mathrm{n}=5)\end{array}$ \\
\hline \multicolumn{7}{|l|}{ Microphytoplankton } \\
\hline Chaetoceros constrictus & - & - & - & $1.4(1.40)$ & - & - \\
\hline C. criophilus & - & - & $0.8(0.58)$ & - & - & $0.2(0.20)$ \\
\hline Coscinodiscus spp. & - & - & $3.8(2.42)$ & - & $0.2(0.20)$ & - \\
\hline Coretheron criophilum & - & - & - & - & $0.2(0.20)$ & - \\
\hline Cylindrotheca closterium & - & - & $0.8(0.80)$ & - & - & - \\
\hline Fragilaria kerguelensis & $21.2(4.90)$ & $17.3(9.78)$ & $37.4(15.67)$ & $9.8(5.85)$ & $9.6(6.13)$ & $4.7(2.34)$ \\
\hline Guinardia flaccida & - & - & - & - & $4.8(3.10)$ & - \\
\hline Nitzschia spp. (cells) & $3.6(1.47)$ & $3.6(1.86)$ & $22.2(10.86)$ & $4.4(1.94)$ & $3.0(1.77)$ & $3.4(1.57)$ \\
\hline Nitzschia spp. (chains) & $28.8(6.17)$ & $6.0\{3.06\}$ & $19.4(7.96)$ & $8.0(4.18)$ & $6.2(3.39)$ & $6.8(2.34)$ \\
\hline N. pelagica & - & - & - & - & $0.2(0.20)$ & - \\
\hline Rhizosolenia spp. & - & $0.3(0.33)$ & $3.0(1.22)$ & $1.0(0.78)$ & - & $1.6(1.37)$ \\
\hline Thalassiosira spp. & $5.8(1.94)$ & $5.0(0.88)$ & $1.2(0.74)$ & $9.6\{3.94\}$ & $8.4(2.96)$ & $3.0(0.63)$ \\
\hline Distephanus speculum & - & - & $0.8(0.58)$ & - & - & - \\
\hline Ceratium spp. & $0.8(0.59)$ & $3.7(0.88)$ & $2.2(0.81)$ & $3.4(1.70)$ & $0.4(0.25)$ & $0.8(0.38)$ \\
\hline Exuviaella spp. & - & - & - & - & - & $0.8(0.58)$ \\
\hline \multicolumn{7}{|l|}{ Microzooplankton } \\
\hline Amphidinium spp. & - & $2.3(1.86)$ & $1.4(0.75)$ & $3.4(2.56)$ & $2.2(1.50)$ & - \\
\hline Amphisolenia spp. & - & - & - & $2.8(0.20)$ & $2.0(1.38)$ & $0.4(0.14)$ \\
\hline Dinophysis spp. & - & - & $2.8(1.72)$ & $0.8(0.38)$ & $1.4(0.51)$ & - \\
\hline Procentrum spp. & - & - & $1.6(1.37)$ & $0.2(0.20)$ & $0.4(0.25)$ & - \\
\hline Peridinium spp. & $1.4(0.51)$ & $1.7(0.88)$ & $0.4(0.41)$ & $2.8(2.56)$ & $1.6(0.87)$ & $0.5(0.25)$ \\
\hline Strombidium spp. (?) & $0.8(0.59)$ & - & $1.4(0.51)$ & - & - & - \\
\hline Tintinnopsis campanula & - & - & - & $0.2(0.20)$ & - & - \\
\hline Tintinnids & $1.6(0.51)$ & $0.7(0.77)$ & $5.0(1.93)$ & $9.6(5.31)$ & $7.4(2.77)$ & $1.6(0.40)$ \\
\hline Aloricate ciliates & $12.6(1.81)$ & $15.7(2.03)$ & $44.8(13.09)$ & $30.8(9.31)$ & $17.2(6.06)$ & $9.0(1.25)$ \\
\hline \multicolumn{7}{|l|}{ Mesozooplankton } \\
\hline Crustacean fragments (large) & $5.4(0.93)$ & $11.7(1.45)$ & $4.4(1.78)$ & $5.0(1.35)$ & $2.6(0.68)$ & $5.6(0.40)$ \\
\hline Crustacean appendages & $6.8(2.84)$ & $3.7(1.86)$ & $7.8(2.64)$ & $10.2(3.65)$ & $4.8(4.08)$ & $6.2(1.66)$ \\
\hline Polychaete setae & $3.8(0.86)$ & $4.7(2.91)$ & $5.6(2.42)$ & $3.6(1.03)$ & $3.2(1.12)$ & $3.6(1.56)$ \\
\hline Unidentified round bodies & - & $0.3(0.33)$ & $0.6(0.40)$ & $0.6(0.60)$ & $1.6(0.82)$ & $2.0(0.55)$ \\
\hline Total items identified & 92.6 & 93.1 & 167.4 & 107.6 & 77.4 & 50.2 \\
\hline
\end{tabular}

ence of very large swarms, have higher rates of consumption been estimated (i.e. $45 \%$ of total primary production; von Bodungen 1986). Our results show that at 4 out of the 14 stations investigated krill were grazing over $10 \%$ of the local production (Table 4 ). The impact was highest at Stn WR-16, where $-51 \%$ of the total production was consumed.

Throughout the transect, gut pigment levels were directly related to the concentration of ambient chlorophyll $a$ and in particular to the portion retained by $20 \mu \mathrm{m}$ filters, the micro size class. Although this size class dominated the phytoplankton stock at all stations located in the region of the seasonal ice retreat (approx. south of $60^{\circ} \mathrm{S}$ ), krill gut pigment levels and grazing impact were not consistently high in this area (Fig 6, Table 4). This implies that, although krill may preferentially select the micro size class, the taxonomic composition of this phytoplankton group may also be an important factor determining their feeding activity. The highest gut pigment contents were generally associated with the dominance of chain-forming Nitzschia spp. or Corethron criophilum in the diatom assem- blage. With some exceptions, the lowest levels were recorded at stations dominated by Chaetoceros dichaeta, Chaetoceros criophilus or by a mixture of Chaetoceros spp. and Rhizosolenia spp. (Table 1). Both Nitzschia spp. and C. criophilum have commonly been found in the stomach contents of Euphausia superba and are regarded as staple food items in its diet (Marr 1962, Kawamura 1981, Schnack 1985, Miller \& Hampton 1989, Daly 1990). In our study, Nitzschia spp. cells and chains generally dominated the microphytoplankton component of krill gut contents whereas C. criophilum did not occur at the stations where krill were collected for gut content analysis. The genera Chaetoceros and Rhizosolenia are usually poorly represented in the gut contents of krill and, although Meyer \& El Sayed (1983) found that krill incubated in glass aquaria could consume these diatoms efficiently, some studies have concluded that they are actually rejected or avoided (Nemoto 1968, Kawamura 1981, Marchant \& Nash 1986, Maciejewska \& Opalinski 1993, Opalinski et al. 1997). Our analysis of krill gut contents supports this conclusion as both Chaetoceros spp. and Rhi- 
zosolenia spp. were generally not ingested, even when they occurred in large concentrations in the water column (Table 5).

Other studies have concluded that swarms of krill may locally consume 60 to $80 \%$ (Holm-Hansen \& Huntley 1984) or even $>100 \%$ (Samyshev 1985) of the total phytoplankton production. However, these conclusions were based on indirect estimates of the energetic requirements of krill and on the assumption that all krill carbon demands are met through an herbivorous diet, at least during the summer season. We believe that this is incorrect and suggest that, even during summer, krill consume a substantial portion of meso- and microzooplankton. Evidence for this can be found through a survey of the results of krill gut content analysis and by considering the daily carbon rations obtained in our study.

Crustaceans and protozoans have consistently been found in the stomach contents of krill, during both winter and summer (Marr 1962, Hopkins 1985, Marchant \& Nash 1986, Daly 1990, Huntley et al. 1994.
Nishino \& Kawamura 1994). Also, grazing experiments have shown that krill can feed very efficiently on copepods, especially when these occur in high densities during summer (Price et al. 1988). During the EPOS study, conducted in spring-summer 1988-1989, Graneli et al. (1993) found that when krill were incubated in a mixture of naturally occurring phytoplankton and copepods they would prey selectively on the zooplankton until they had virtually eliminated them, and only then would krill start consuming algal cells. These authors suggested that this was probably due to the high protein and lipid content of copepods, which would make them a better quality food relative to diatoms of similar size (Graneli et al. 1993). The results of our analysis of krill stomachs confirm the importance of micro- and mesozooplankton organisms in its diet. At 3 out of the 6 stations examined, bodies and fragments of these organisms constituted over $50 \%$ of the total recognizable fraction of the gut contents (Table 5). This shows that Euphausia superba is a true omnivore and, even during summer, supplements its algal diet with a large heterotrophic carbon component.

Table 6. Euphausia superba Dana. Estimates of the daily ration in the Antarctic krill

\begin{tabular}{|c|c|c|}
\hline Daily ration & Conditions, food, method & Source \\
\hline $2.9-8.7^{\circ}$, mean 5.0 & Calculated from energy budget & Chekunova \& Rynkova (1974) \\
\hline $0.02-1.66^{\mathrm{b}}(30-50 \mathrm{~mm})$ & $\begin{array}{l}\text { Estimated from ingestion rates and calculated from } \\
\text { energy budget of Clarke \& Morris (1983) }\end{array}$ & Antezana et al. (1982) \\
\hline $\begin{array}{l}2.9-3.9^{b}(19-35 \mathrm{~mm}) \\
1.1-1.5^{b}(35-55 \mathrm{~mm})\end{array}$ & $\begin{array}{l}\text { Estimated from in vitro filtration rates with a culture of } \\
\text { Dunaliella as food }\end{array}$ & Kato et al. (1982) \\
\hline $5.0-6.0^{c}$ & Calculated from energy budget & Clarke \& Morris (1983) \\
\hline $0.86-5.63^{b}$ mean 2.0 & $\begin{array}{l}\text { Estimated with radiocarbon method using cultures of } \\
\text { phytoplankton and detritus from flagellates as food }\end{array}$ & Samyshev \& Lushov (1983) \\
\hline $2.3-9.0^{b}$ & $\begin{array}{l}\text { Estimated from in vitro ingestion rates with net phyto- } \\
\text { plankton, furcilia of E. superba and infusoria as food }\end{array}$ & Boyd et al. (1984) \\
\hline $\begin{array}{l}2.6-17.1^{b}(30-35 \mathrm{~mm}) \\
0.8-2.4^{b}(40-45 \mathrm{~mm}) \\
0.9-3.2^{b}(50-55 \mathrm{~mm})\end{array}$ & $\begin{array}{l}\text { Estimated from in vitro ingestion rates with net } \\
\text { phytoplankton as food }\end{array}$ & Schnack $(1985)$ \\
\hline $17-28^{d}$ & $\begin{array}{l}\text { Estimated from faecal pellet evacuation rates using net } \\
\text { phytoplankton as food }\end{array}$ & Clarke et al. (1988) \\
\hline $8.5^{b}$ & Calculated from energy budget & Price et al. (1988) \\
\hline $0.53-5.81^{b}$ & $\begin{array}{l}\text { Estimated from filtration rates using zooplankton and } \\
\text { Artemia nauplin as food }\end{array}$ & Krylov (1989) \\
\hline $\begin{array}{l}0.93-2.72^{d} \\
5.0-7.3^{d}\end{array}$ & $\begin{array}{l}\text { Estimated from in situ gut pigment contents } \\
\text { Estimated from in vitro gut pigment contents }\end{array}$ & Ponomareva \& Kuznetsova (1989) \\
\hline $0.31-5.76^{b}$ & Estimated from gut evacuation and ingestion rates & Drits \& Semenova (1989) \\
\hline $\begin{array}{l}2-52^{\star} \text { (furcilia } 3-6 \text { ), } \\
\text { realistically } 10\end{array}$ & Estimated from gut evacuation rates & Daly (1990) \\
\hline $\begin{array}{l}19.7^{b} \text { (calyptopis } 1-2 \text { ) } \\
4.4^{b} \text { (furcilia } 4-5 \text { ) }\end{array}$ & $\begin{array}{l}\text { Estimated from in situ and in vitro filtration rates using } \\
\text { net phytoplankton as food }\end{array}$ & Huntley \& Brinton (1991) \\
\hline $0.05^{\mathrm{b}}(38-55 \mathrm{~mm})$ & Estimated from gut evacuation and ingestion rates & Drits \& Pasternak (1993) \\
\hline $0.8-3.67^{\circ}(20-40 \mathrm{~mm})$ & Estimated from physiological model & Huntley et al. (1994) \\
\hline $\begin{array}{l}\text { aPercentage of wet body } \\
\text { "Percentage of body wei }\end{array}$ & $\begin{array}{l}{ }^{b} \text { Percentage of body carbon } \\
\text { a Percentage of dry body weight }\end{array}$ & \\
\hline
\end{tabular}


This is supported by the low daily carbon rations obtained from our measurements of carbon-specific ingestion rates for krill grazing on phytoplankton. Daily rations can be calculated from krill length $(L)$ measurements using the empirical equations of Kato et al. (1982) for the conversion into dry weight units, DW $=1.208 \exp (0.104 L)$, and of Ikeda \& Bruce (1986) for the conversion into carbon units, $C=42.6-47.1 \%$ DW. The resulting figures show that at all stations situated to the north of the pack ice (from Stn WR-5 to Stn WR-24) krill carbon rations, based on chorophyll alone, were very low, in the range 0.15 to $1.68 \%$ of body carbon per day. A high daily ration, in excess of $13 \%$ of body carbon, was recorded only at Stn WR-2, at the edge of the pack ice, which exhibited a phytoplankton bloom with

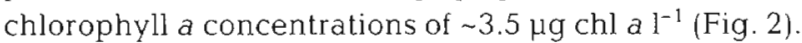
With this exception the daily rations obtained in this study, which are derived from a purely autotrophic food source, are among the lowest recorded for Euphausia superba during the summer season (Table 6). It is widely accepted that krill requires a ration of $\sim 0.80$ to $2.8 \%$ per day to meet its basic metabolic demands (Clarke et al. 1988, Daly 1990, Huntley et al. 1994). These do not include the energetic costs for growth, molting and reproduction. When all these and a high metabolic activity are taken into consideration, then krill daily ration generally ranges between $\sim 5$ and $15 \%$ of body carbon (Table 6). This is the typical situation observed in the spring and summer, when spawning takes place and growth efficiency is maximum.

It is thus clear that only the ration recorded at Stn WR-2 was sufficiently high for krill to obtain all their energetic requirements exclusively from a phytoplankton diet. Elsewhere along the transect, most of the energetic demands of the krill population were apparently met by using a heterotrophic source of carbon such as meso- and microzooplankton.

We suggest, therefore, that although Antarctic krill can still be regarded as essentially herbivorous in the presence of dense phytoplankton blooms, through most of its distribution range in the summer it may consume a larger proportion of zooplankton than previously supposed. Some of the previous estimates of the energy budget of krill during its reproductive season have not allowed for sufficient energy input except at unrealistically high phytoplankton concentrations. A substantial utilization of heterotrophic carbon through predation on zooplankton may provide a solution to the balance of its energy budget. It is clear from our study that, even when krill ingestion rates are corrected for evacuation rates and pigment destruction in the gut, phytoplankton accounts for a small fraction of the daily ration of krill. There is an urgent need, therefore, to place more emphasis on characterising and quantifying the feeding of krill on non-algal prey.
Acknowledgements. We are grateful to the South African Department of Environment Affairs \& Tourism and to Rhodes University (Grahamstown) for providing funds and facilities for this study. Special thanks go to a number of our colleagues for allowing the use of their data on chlorophyll a concentrations (J. Mantel), primary production rates ( $R$. K. Laubscher), temperature and salinity $(R . C$. van Ballegooyen and $H$. R. Valentine). We also thank the officers and crew of the SA 'Agulhas' for their cooperation and the technological \& engeneering sections of the Sea Fisheries Research Institute (Cape Town) for their assistance at sea.

\section{LITERATURE CITED}

Antezana T, Ray K, Melo C (1982) Trophic behaviour of Euphausia superba Dana in laboratory conditions. Polar Biol 1:77-82

Berman T, Kimor B (1983) A large scale filtration apparatus for net plankton sampling. J Plankton Res 5:111-116

Bodungen B von (1986) Phytoplankton growth and krill grazing during spring in the Branfield Strait, Antarcticaimplications from sediment trap collections. Polar Biol 6: $153-160$

Boyd CM, Heyraud M, Boyd CN (1984) Feeding of the Antarctic krill Euphausia superba. J Crustac Biol 4:123-141

Cadée GC, González H, Schnack-Schiel SB (1992) Krill diet affects faecal string setting. Polar Biol 12:75-80

Chekunova VI, Rynkova TI (1974) Energy requirements of the Antarctic crustacea Euphausia superba Dana. Oceanology $14: 434-440$

Clarke A, Morris DJ (1983) Towards an energy budget for krill: the physiology and biochemistry of Euphausia superba Dana. Polar Biol 2:69-86

Clarke A, Quetin LB, Ross RM (1988) Laboratory and field estimates of the rate of faecal pellet production by Antarctic krill, Euphausia superba. Mar Biol 98:557-563

Comiso JC, McClain CR, Sullivan CW, Ryan JP, Leonard CL (1993) Coastal zone color scanner pigment concentrations in the Southern Ocean and relationships to geophysical surface features. J Geophys Res 98:2419-2451

Conover RJ, Durvasula R, Roy S, Wang R (1986) Probable loss of chlorophyll-derived pigments during passage through the gut of zooplankton and some of the consequences. Limnol Oceanogr 31:878-887

Dagg MJ, Grill DW (1980) Natural feeding rates of Centropages typicus females in the New York Bight. Limnol Oceanogr 25:597-609

Daly KL (1990) Overwintering development, growth, and feeding of larval Euphausia superba in the Antarctic marginal ice zone. Limnol Oceanogr 35:1564-1576

Dam HG, Peterson WT (1988) The effect of temperature on the gut clearance rate constant of planktonic copepods J Exp Mar Biol Ecol 123:1-14

Drits AV, Pasternak AF (1993) Feeding of dominant species of the Antarctic herbivores zooplankton. In: Voronina NM (ed) Pelagic ecosystems of the Southern Ocean. Nauka Press, Moscow, p 250-259 (in Russian)

Drits AV, Semenova TN (1989) Trophic characteristics of major planktonic phytophagous from the South Shetland Islands region during early spring. In: Ponomareva LA (ed) Complex investigations of the pelagian zone of the Southern Ocean. Shirshov Institute of Oceanology Publishers, Moscow, p 66-78 (in Russian)

Ellis SG. Small LF (1989) Comparison of gut-evacuation rates of feeding and non-feeding Calanus marshallae. Mar Biol 103:175-181 
Everson I, Watkins JL, Bone DG, Foote KG (1990) Implications of a new acoustic target strength for abundance estimates of Antarctic krill. Nature 345:338-340

Granéli E, Granéli W, Rabbani MM, Daugbjerg N, Fransz G, Cizin-Roudy J, Alder VA (1993) The influence of copepod and krill grazing on the species composition of phytoplankton communties from the Scotia-Weddell Sea. Polar Biol 13:201-213

Greene CH, Stanton TK, Wiebe PH, McClatchie S (1991) Acoustic estimates of Antarctic krill. Nature 349:110

Hasle GR (1978) The inverted microscope method. In: Sournia A (ed) Monographs on oceanographic methodology, no. 6 , phytoplankton manual. UNESCO, Paris, p 88-96

Head EJH (1992) Gut pigment accumulation and destruction by arctic copepods in vitro and in situ. Mar Biol 112: $583-592$

Head EJH, Harris LR (1992) Chlorophyll and carotenoid transformation and destruction by Calanus sp. grazing on diatoms. Mar Ecol Prog Ser 86:229-238

Hewes CD, Sakshaug E, Reid FMH, Holm-Hansen O (1990) Microbial autotrophic and heterotrophic eucaryotes in Antarctic waters: relationships between biomass and chlorophyll, adenosine triphosphate and particulate organic carbon. Mar Ecol Prog Ser 63:27-35

Hewitt DA, Demer DA (1991) Krill abundance. Nature 353 : 310

Holdgate MW (1967) The Antarctic midwater ecosystem. Phil Trans R Soc Lond B Biol Sci 152:363-383

Holm-Hansen O, Huntley M (1984) Feeding requirements of krill in relation to food sources. J Crustac Biol 4:156-178

Hopkins TL (1985) Food web of an Antarctic midwater ecosystem. Mar Biol 89:197-21.2

Huntley M, Brinton E (1991) Mesoscale variation in growth and early development of Euphausia superba Dana in the Western Bransfield Strait region. Deep Sea Res 38 : $1213-1240$

Huntley ME, Marin V, Escritor F (1987) Zooplankton grazers as transformers of ocean optics: a dynamic model. J Mar Res 45:911-945

Huntley M, Nordhausen W, Lopez MDG (1994) Elemental composition, metabolic activity and growth of Antarctic krill Euphausia superba during winter. Mar Ecol Prog Ser $107: 23-40$

Ikeda T, Bruce B (1986) Metabolic activity and elemental composition of krill and other zooplankton from Prydz Bay, Antarctica, during early summer. Mar Biol 92:545-555

JGOFS (Joint Global Ocean Flux Study) (1990) Core measurements protocols, JGOFS report No. 6. Scientific Committee on Oceanic Research, International Council of Scientific Unions, p 1-40

Kato M, Segawa S, Tanoue E, Murano M (1982) Filtering and ingestion rates of the Antarctic krill, Euphausia superba Dana. Trans Tokyo Univ Fish 5:167-175

Kawamura A (1981) Food habits of Euphausia superba and the diatom community. BIOMASS Scient Ser 2:65-68

Kiørboe T, Tiselius PT (1987) Gut clearance and pigment destruction in a herbivorous copepod, Acartia tonsa, and the determination of in situ grazing rates. J Plankton Res 9: 525-534

Krylov PI (1989) Carnivore feeding of Euphausia superba Dana. In: Ponomareva LA (ed) Complex investigations of the pelagian zone of the Southern Ocean. Shirshov Institute of Oceanology Publishers, Moscow, p 94-105 (in Russian)

Lasker R (1966) Feeding, growth, respiration and carbon utilization of a euphausiid crustacean. J Fish Res Bd Can 23:1291-1317
Laubscher RK, Froneman PW, McQuald CD, Dower KM (in press) Size-fractionated primary production in the Atlantic sector of the Southern Ocean: implications for the food web. Deep Sea Res

Lopez MDG, Huntley ME, Syles PF (1988) Pigment destruction by Calanus pacificus: Impact on the estimation of water column fluxes. J Plankton Res 10:715-734

Maciejewska K, Opalinski KW (1993) Spatial and temporal differentiation of food in Antarctic krill, Euphausia superba. Pol Arch Hydrobiol 40:291-311

Mackas D, Bohrer R (1976) Fluorescence analysis of zooplankton gut contents and an investigation of diel feeding patterns. J Exp Mar Biol Ecol 25:77-85

Marchant HJ, Nash GV (1986) Electron microscopy of gut contents and faeces of Euphausia superba Dana. Mem Natl Inst Polar Res Ser E Biol Med Sci 40:167-177

Marr J (1962) The natural history and geography of the Antarctic krill (Euphausia superba Dana). Discovery Rep 32: $33-464$

Mathew KJ (1988) Net avoidance behaviour among larval, juvenile, and adult euphausiids. J Mar Biol Assoc India 30:93-98

Mayzaud P, Razouls S (1992) Degradation of gut pigment during feeding by a subantarctic copepod: importance of feeding history and digestive acclimation. Limnol Oceanogr 37:393-404

Meyer MA, El-Sayed SZ (1983) Grazing of Euphausia superba Dana on natural phytoplankton populations. Polar Biol 1: $193-197$

Miller DGM, Hampton I (1989) Biology and ecology of the Antarctic krill (Euphausia superba Dana): a review. BIOMASS Scient Ser 9:1-166

Morris DJ (1984) Filtration rates of Euphausia superba Dana: under- or overestimates? J Crustac Biol 4:185-197

Morris DJ, Ricketts C (1984) Feeding of krill around South Georgia. I: a model of feeding activity in relation to depth and time of day. Mar Ecol Prog Ser 16:1-7

Nemoto T (1968) Chlorophyll pigments in the stomachs of euphausids. J Oceanogr Soc Jpn 24:253-260

Nishino Y, Kawamura A (1994) Winter gut contents of Antarctic krill (Euphausia superba Dana) collected in the South Georgia area. Proc NIPR Symp Polar Biol 7:82-90

Nordhausen W (1994) Winter abundance and distribution of Euphausia superba, E. crystallorophias, and Thysanoessa macrura in Gerlache Strait and Crystal Sound, Antarctica. Mar Ecol Prog Ser 109:131-142

Opalınski KW, Maciejewska K, Georgieva LV (1997) Notes on food selection in the Antarctic krill, Euphausia superba. Polar Biol 17:350-357

Pakhomov EA, Perissinotto $R$, Froneman PW, Miller DGM (1997) Energetics and feeding dynamics of Euphausia superba in the South Georgia region during the summer of 1994. J Plankton Res 19:399-423

Penry DL, Frost AV (1990) Re-evaluation of the gut fullness (gut fluorescence) method for inferring ingestion rates of herbivorous copepods. Limnol Oceanogr 35:1207-1214

Penry DL, Frost AV (1991) Chlorophyll-a degradation by Calanus pacificus: dependence on ingestion rate and digestive acclimation to food resources. Limnol Oceanogr $36: 147-159$

Perissinotto R (1992) Mesozooplankton size-selectivity and grazing impact on the phytoplankton community of the Prince Edward Archipelago (Southern Ocean). Mar Ecol Prog Ser 79:243-258

Perissinotto R, Pakhomov EA (1996) Gut evacuation rates and pigment destruction in the Antarctic krill Euphausia superba. Mar Biol 125:47-54 
Peterson W, Painting SJ, Hutchings L (1990) Diel variations in gut pigment content, diel vertical migration and estimates of grazing impact for copepods in the southern Benguela upwelling region in October $1987 \mathrm{~J}$ Plankton Res 12 $259-281$

Ponomareva LA, Kuznetsova IA (1989) Food and rations of the Euphausia superba in the south part of the Scotia Sea. In: Ponomareva LA (ed) Complex investigations of the pelagian zone of the Southern Ocean. Shirshov Institute of Oceanology Publishers, Moscow, p 86-93 (in Russian)

Price HJ, Boyd KR, Boyd CM (1988) Omnivorous feeding behaviour of the Antarctic krill Euphausia superba. Mar Biol 97:67-77

Priddle J, Watkins J, Morris D, Ricketts C, Burchholz F (1990) Variation of feeding by krill swarms. J Plankton Res 12 $1189-1205$

Quetin LB, Ross RM, Amsler MO (1987) Field ingestion rates of Euphausia superba. EOS 68:1785

Samyshev EZ (1985) Distribution and production of the Antarctic krill. In: Vinogradov ME, Flint MV (eds) Biological basis for the fishery utilization of open regions of the Ocean. Nauka Press, Moscow, p 40-49 (in Russian)

Samyshev EZ, Lushov AI (1983) Feeding and its components of the Antarctic krill. Oceanology 23:1018-1022

SC-CAMLR (1991) Report of the tenth meeting of the scientific committee (SC-CAMLR-X). CCAMLR, Hobart, Australia

Schnack SB (1985) Feeding by Euphausia superba and copepod species in response to varying concentrations of phytoplankton. In: Siegfried WR, Condy PR, Laws RM (eds) Antarctic nutrient cycles and food webs. Springer, Berlin, p 311-323

Editorial responsibility: Otto Kinne (Editor),

Oldendorf/Luhe, Germany
Simard Y, Lacroix G, Legendre L (1985) In situ twilight grazing rhythm during diel vertical migrations of a scattering layer of Calanus finmarchicus. Limnol Oceanogr 30 598-606

SIMRAD (1991) EK 500 Scientific Echo Sounder: operator manual. Simrad Subsea A/S, Horten, Norway, p 112

Smetacek V, Scharek R, Nothing EM (1990) Seasonal and regional variation in the pelagial and its relationship to the life history cycle of krill. In: Kerry KR, Hempel G (eds) Antarctic ecosystems, ecological change and conservation. Springer, Berlin, p 103-114

Stanton TK, Nash RDM, Eastwood RL, Nero RW (1987) A field examination of acoustical scattering from marine organisms at $70 \mathrm{kHz}$. IEEE (Inst Electr Electron Eng) J Ocean Eng OE-12:339-348

Strickland JDH, Parsons TR (1968) A practical handbook of seawater analysis. Bull Fish Res Bd Can 167

Tanoue E, Hara S (1986) Ecological implications of faecal pellets produced by the Antarctic krill Euphausia superba in the Antarctic Ocean. Mar Biol 91:359-369

Tseytlin VB, Pasternak AF, Drits AV (1991) Does gut passage time in copepod depend on food concentration? Oceanology $31: 155-161$

Wang R, Conover RJ (1986) Dynamics of gut pigment in the copepod Temora longicornis and the determination of in situ grazing rates. Limnol Oceanogr 31:867-877

Welschmeyer NA (1994) Fluorometric analysis of chlorophyll $a$ in the presence of chlorophyll $b$ and phaeopigments. Limnol Oceanogr 39:1985-1992

Willason SW, Cox JL (1987) Diel feeding, laminarinase activity and phytoplankton consumption by euphausiids. Biol Oceanogr 4:1-24

Submitted: October 10, 1996; Accepted: September 25, 1997 Proofs received from author(s): December 4, 1997 